\title{
The Structures of a $\beta$-Galactosidase Inhibitor, Galactostatin, and Its Derivatives
}

\author{
Yukio MiYake and Mitsuo Ebata \\ Shionogi Research Laboratories, Shionogi \& Co., Ltd., \\ Fukushima-ku, Osaka 553, Japan
}

Received August 27, 1987

\begin{abstract}
The structure of the $\beta$-galactosidase inhibitor, galactostatin, isolated from Streptomyces lydicus PA-5726 was determined to be 5-amino-5-deoxygalactopyranose, in which the ring oxygen of galactose has been replaced by nitrogen. For this study, two derivatives of galactostatin were prepared by oxidation and reduction, respectively. The oxidation product of galactostatin was 5amino-5-deoxygalactonic- $\delta$-lactam (galactostatin-lactam) and the reduction product was 5-amino1,5-dideoxygalactopyranose (1-deoxygalactostatin).
\end{abstract}

Several $\beta$-galactosidase inhibitors have recently been isolated from the culture broth of microorganisms. ${ }^{1 \sim 3)}$ We examined the culture broth of Actinomycetes obtained from soil samples and isolated a new $\beta$-galactosidase inhibitor, named galactostatin, from the culture filtrate of Streptomyces lydicus PA-5726, as reported in the previous paper. ${ }^{4)}$

In a preliminary structural study, we proposed that galactostatin is one of the piperidinose sugars, which have been studied not only because of their chemical interest ${ }^{5}$ but also as biological active substances. ${ }^{6 \sim 8)}$ In the present study, we investigated the structures of galactostatin and two derivatives of it which were prepared by iodine oxidation and catalytic reduction, respectively. The scheme for the preparation of these derivatives is shown in Fig. 1. In this paper, we describe their structures and some of their characteristics.

\section{RESULTS AND DISCUSSION}

Galactostatin (1) is a slightly hygroscopic, white amorphous powder. It is stable under acidic and neutral conditions but unstable in basic media. The IR spectrum of 1 (Fig. 2) shows that hydroxy and imino groups (3360, $2900,1650 \mathrm{~cm}^{-1}$ ) are present, but they are not clearly apparent due to its hygroscopic nature. The EI-MS spectrum of 1 (Fig. 2) showed the parent ion at $m / z 161\left(\mathrm{M}^{+}-18\right)$. Successive dehydration of 1 gave fragments of $m / z 143$ and 125 , and the successive release of hy-

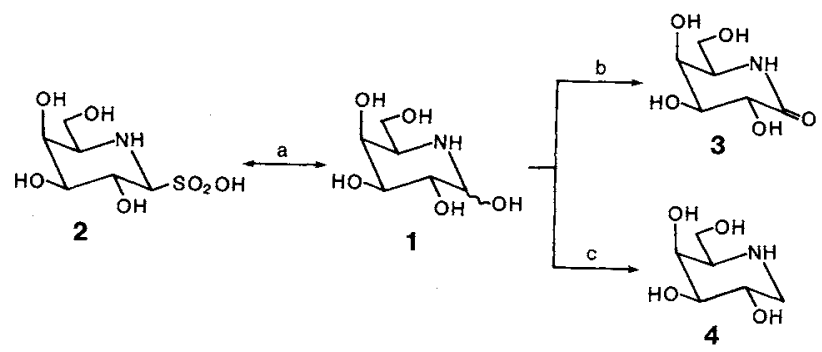

FIG. 1. Relationship among Galactostatin and Its Derivatives.

1, galactostatin; 2 , galactostatin bisulfite adduct; 3 , galactostatin-lactam; 4, 1-deoxygalactostatin.

a) $\mathrm{H}_{2} \mathrm{SO}_{3}$; b) $\mathrm{I}_{2}, \mathrm{NaOH}$; c) $\mathrm{H}_{2}, \mathrm{PtO}_{2}$. 

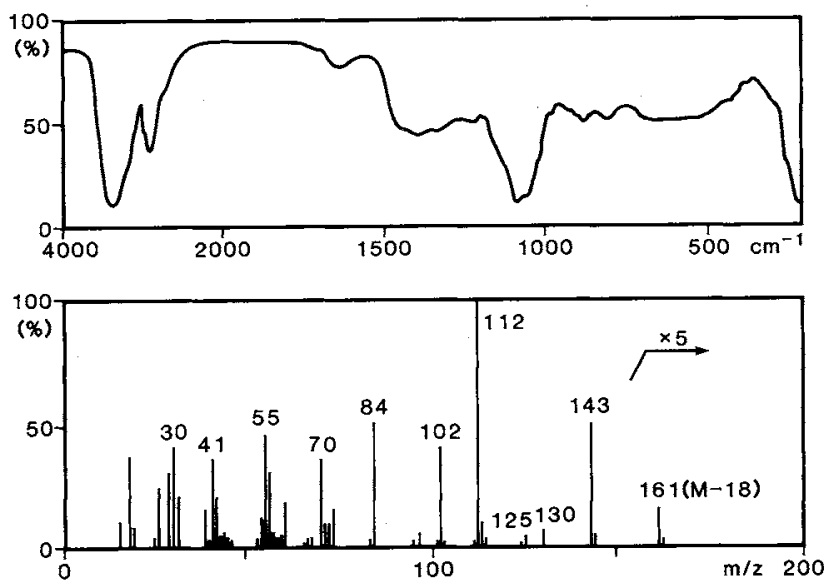

FIG. 2. IR $(\mathrm{KBr})$ and EI-MS Spectra of Galactostatin.

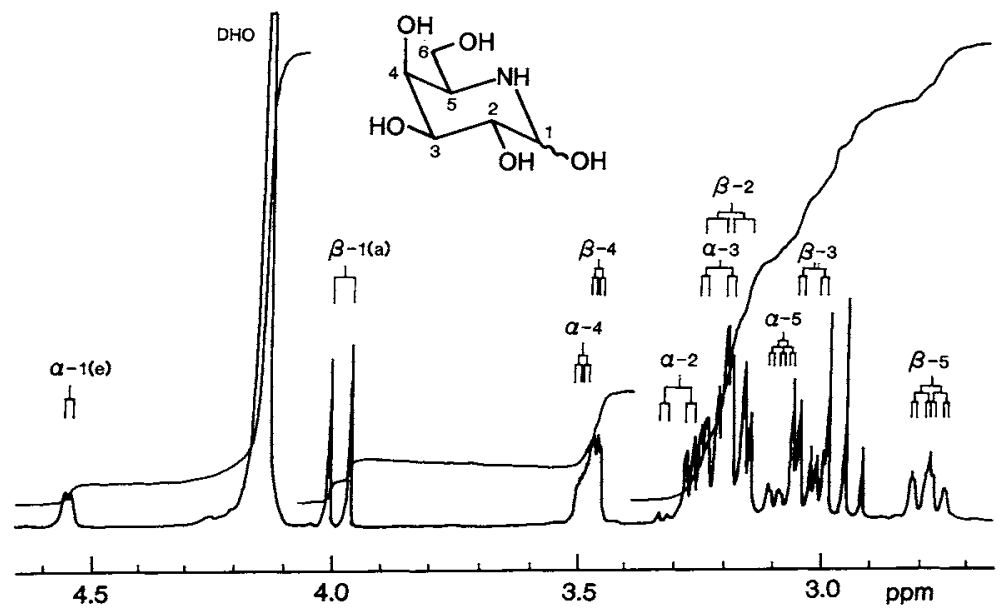

Frg. 3. ${ }^{\mathrm{t}} \mathrm{H}$ NMR Spectrum of Galactostatin in $0.5 \mathrm{~N} \mathrm{DCl}$.

droxymethylene and water from the parent ion gave peaks at $m / z 130\left(161-\mathrm{CH}_{2} \mathrm{OH}\right), 112$ (base ion) and 94. These mass spectral data and elemental analysis results indicate that the molecular formula of 1 is $\mathrm{C}_{6} \mathrm{H}_{13} \mathrm{NO}_{5}$ (MW 179.17).

Galactostatin bisulfite adduct (2) was obtained as colorless needles. This substance is soluble in water, dimethyl sulfoxide and methanol, but its solubility is less than that of 1 . The IR spectrum of $\mathbf{2}$ revealed hydroxy $\left(\sim 3400,1140,1100\right.$ and $\left.1050 \mathrm{~cm}^{-1}\right)$, imino $\left(3300 \sim 3100 \mathrm{~cm}^{-1}\right)$, sulfur dioxide $\left(1450 \sim 1330 \mathrm{~cm}^{-1}\right)$ and sulfur oxide $(625$ $\mathrm{cm}^{-1}$ ) groupes. The EI-MS spectrum of 2 showed the parent ion at $m / z 161\left(\mathrm{M}^{+}-82\right)$. Its fragmentation pattern was very similar to that of 1. A base ion at $m / z 48(\mathrm{SO})$ and a sulfur dioxide ion at $m / z 64$ were observed. The molecular formula of $\mathbf{2}$ was determined to be $\mathrm{C}_{6} \mathrm{H}_{13} \mathrm{NO}_{7} \mathrm{~S} \cdot \mathrm{H}_{2} \mathrm{O}$ from the elemental analysis results and EI-MS spectral data.

The structure of 1 was determined from the ${ }^{1} \mathrm{H}$ - and ${ }^{13} \mathrm{C}-\mathrm{NMR}$ spectra. The ${ }^{1} \mathrm{H}-\mathrm{NMR}$ spectrum (Fig. 3) shows two signals at lower field, $\delta 4.56\left(J_{1,2}=3.0 \mathrm{~Hz}\right)$ and $\delta 3.99\left(J_{1,2}=\right.$ $9.0 \mathrm{~Hz})$. These two doublets were assigned to equatorial and axial anomeric protons, respectively. This indicates that 1 exists in $\alpha$ and $\beta$ forms, as shown in Table I. For the $\alpha$ form, 
Table I. ${ }^{1}$ H NMR Data for Galactostatin (1)

\begin{tabular}{|c|c|c|c|c|}
\hline \multirow{2}{*}{ Proton } & \multicolumn{2}{|c|}{$\alpha$ Form } & \multicolumn{2}{|c|}{$\beta$ Form } \\
\hline & $\delta \mathrm{m}$ & $J(\mathrm{~Hz})$ & $\delta \mathrm{m}$ & $J(\mathrm{~Hz})$ \\
\hline $1-\mathrm{H}$ & $4.56 \mathrm{~d}$ & 3.0 & $3.99 \mathrm{~d}$ & 9.0 \\
\hline $2-\mathrm{H}$ & $3.29 \mathrm{dd}$ & $3.0,10.3$ & $3.19 \mathrm{dd}$ & $9.0,10.0$ \\
\hline $3-\mathrm{H}$ & $3.21 \mathrm{dd}$ & $2.8,10.3$ & $3.02 \mathrm{dd}$ & $2.9,10.0$ \\
\hline $4-\mathrm{H}$ & $3.49 \mathrm{dd}$ & $1.4, \quad 2.8$ & $3.46 \mathrm{dd}$ & $1.4, \quad 2.9$ \\
\hline $5-\mathrm{H}$ & $3.08 \mathrm{dt}$ & $1.4,4.1$ & $2.77 \mathrm{ddd}$ & $\begin{array}{l}1.4,6.0, \\
7.4\end{array}$ \\
\hline $6,6^{\prime}-\mathrm{H}$ & \multicolumn{2}{|l|}{$3.17 \sim 3.20^{a}$} & \multicolumn{2}{|c|}{$3.17 \sim 3.20^{a}$} \\
\hline
\end{tabular}

Chemical shifts are given relative to TMS, the external standard.

${ }^{a}$ The 6 and $6^{\prime}-\mathrm{H}$ signals of the $\alpha$ and $\beta$ forms overlap.

TABle II. ${ }^{13} \mathrm{C}$ NMR Data for Galactostatin (1)

\begin{tabular}{|c|c|c|c|c|c|c|}
\hline \multirow{2}{*}{ Carbon } & \multicolumn{3}{|c|}{$\alpha$ Form } & \multicolumn{3}{|c|}{$\beta$ Form } \\
\hline & $0.5 \mathrm{NDCl}^{a}$ & $\mathrm{D}_{2} \mathrm{O}^{b}$ & $\mathrm{~m}$ & $0.5 \mathrm{NDCl}^{a}$ & $\mathrm{D}_{2} \mathrm{O}^{b}$ & $\mathrm{~m}$ \\
\hline C-1 & 78.8 & 80.0 & $d$ & 82.2 & 83.7 & $\mathrm{~d}$ \\
\hline $\mathrm{C}-2$ & 67.8 & 70.3 & $d$ & 71.3 & 74.3 & d \\
\hline$C-3$ & 69.3 & 71.1 & $\mathrm{~d}$ & 72.3 & 74.5 & d \\
\hline$C-4$ & 67.6 & 69.8 & $\mathrm{~d}$ & 67.2 & 69.4 & $d$ \\
\hline $\mathrm{C}-5$ & 54.4 & 52.5 & $\mathrm{~d}$ & 57.4 & 56.1 & d \\
\hline$C-6$ & 59.6 & 62.7 & $\mathrm{t}$ & 59.4 & 62.0 & $\mathrm{t}$ \\
\hline
\end{tabular}

a Chemical shifts are given relative to $\mathrm{CH}_{3} \mathrm{CN}(\delta 1.7)$, the internal standard, in $0.5 \mathrm{~N} \mathrm{DCl}$ solution.

$b$ Chemical shifts are given relative to dioxane $(\delta 67.4)$, the internal standard, in $\mathrm{D}_{2} \mathrm{O}$ solution.

the coupling constants indicate that $2-\mathrm{H}, 3-\mathrm{H}$ and $5-\mathrm{H}$ are in axial configurations and $1-\mathrm{H}$ and $4-\mathrm{H}$ are in equatorial ones. In the $\beta$ form, all ring protons except $4-\mathrm{H}$ are in axial configurations. These findings suggest that $\mathbf{1}$ is similar to galactose and exists in the chair form.

The ${ }^{13} \mathrm{C}-\mathrm{NMR}$ spectra of 1 in both $0.5 \mathrm{~N}$ $\mathrm{DCl}$ and $\mathrm{D}_{2} \mathrm{O}$ were assigned as shown in Table II. The signal of the anomeric carbon atom appears at the lowest field. The chemical shifts of C-2, C-3, C-4 and C-6 are similar to those of galactose in $\mathrm{D}_{2} \mathrm{O},{ }^{9,10)}$ but the signals of $\mathrm{C}-1$ and $\mathrm{C}-5$ appear at higher field $(\Delta \delta 13 \sim 20$ ppm). These upfield shifts are due to the lower deshielding effect of the ring nitrogen atom, ${ }^{11}$ ) and thus, C-1 and C-5 are combined to form a hemiacetal ring. These phenomena are also observed in the ${ }^{1} \mathrm{H}-\mathrm{NMR}$ spectrum.

The ring nitrogen atom of 1 was detected as follows. Treatment of 1 with dry $\mathrm{HCl}-\mathrm{MeOH}$ gave a pyridine derivative through dehydration. The product was isolated as colorless crystals, exhibited UV maxima characteristic of 3-hydroxypyridine, ${ }^{12)}$ and was judged to be 2-hydroxymethyl-5-hydroxypyridine from the results of physicochemical analysis. It is known that 5-amino-5-deoxypyranoses lose three moles of water on dehydration, being transformed into 3-hydroxypyridine derivatives. ${ }^{13)}$ This indicated that 1 had a nitrogen atom in its hemiacetal ring like nojirimycin. ${ }^{14)}$ Then, it was determined that $\mathbf{1}$ is a 5 -amino-5deoxygalactopyranose and that it exists in $\alpha$ and $\beta$ forms as general free monosaccharides do. The ratio of the $\alpha$ and $\beta$ anomers of 1 was approximately $1: 2$ in $0.5 \mathrm{~N} \mathrm{DCl}$ and $3: 2$ in $\mathrm{D}_{2} \mathrm{O}$, as determined from the intensities of the anomeric proton and the average heights of carbon signals in the ${ }^{13} \mathrm{C}-\mathrm{NMR}$ spectra. Compound 1 showed mutarotation; $[\alpha]_{\mathrm{D}}^{23}$ $+85.6^{\circ}(2 \mathrm{~min}$, water $) \rightarrow[\alpha]_{\mathrm{D}}^{23}+77.8^{\circ}(24 \mathrm{hr})$.

The ${ }^{1} \mathrm{H}-\mathrm{NMR}$ spectrum of $\mathbf{2}$ showed well separated signals. The anomeric proton of this compound gave a large coupling constant $\left(J_{1,2}=10.1 \mathrm{~Hz}\right)$ due to axial-axial coupling. Therefore, it was concluded that 2 exists exclusively in the $\beta$-pyranose-like form, galactopiperidinosyl-1-sulfonic acid, which is a bisulfite adduct of $\mathbf{1}$, as found for piperidinose compounds. ${ }^{4,5,15)}$

The oxidation product (3) and the reduction product (4) of 1 no longer had reducing power, and they were more stable than 1 . Compound 3 was analyzed as $\mathrm{C}_{6} \mathrm{H}_{11} \mathrm{NO}_{5}$, and its IR spectrum showed the presence of an amide carbonyl group at 1660 and $1630 \mathrm{~cm}^{-1}$. The EI-MS spectrum of 3 showed the parent ion at $m / z 178\left(\mathrm{M}^{+}+1\right)$ and the base ion at $m / z 60$ $\left(\mathrm{CH}_{2} \mathrm{OH}-\mathrm{CH}=\mathrm{NH}_{2}^{+}\right)$. The ${ }^{1} \mathrm{H}-\mathrm{NMR}$ spectrum of 3 in $\mathrm{D}_{2} \mathrm{O}$ showed one less proton signals than in the case of 1 . The signals were assigned as shown in Table III, but the 5-H, 6$\mathrm{H}$ and $6^{\prime}-\mathrm{H}$ protons could not be well analyzed due to the higher order couplings. The ${ }^{13} \mathrm{C}$ NMR spectrum of 3 showed six peaks (Table 
Table III. NMR Data For Galactostatin-lactam (3) and 1-Deoxygalactostatin (4)

\begin{tabular}{|c|c|c|c|c|}
\hline \multirow{2}{*}{ Position } & \multicolumn{2}{|c|}{ Compound 3} & \multicolumn{2}{|l|}{ Compound 4} \\
\hline & $\delta_{\mathbf{H}}$ & $\delta_{\mathrm{C}}$ & $\delta_{\mathrm{H}}$ & $\delta_{\mathrm{C}}$ \\
\hline 1 & - & $174.3 \mathrm{~s}$ & $\begin{array}{l}1.70 \mathrm{dd}(10.4,12.4) \\
2.45 \mathrm{dd}(5.3,12.4)\end{array}$ & $49.9 \mathrm{dd}$ \\
\hline 2 & $3.49 \mathrm{~d}(10.0)$ & $68.6 \mathrm{~d}$ & 3.08 ddd $(5.3,9.8,10.4)$ & $69.0 \mathrm{~d}$ \\
\hline 3 & $3.22 \mathrm{dd}(2.4,10.0)$ & $73.0 \mathrm{~d}$ & $2.80 \mathrm{dd}(3.2,9.8)$ & $75.9 \mathrm{~d}$ \\
\hline 4 & $3.51 \mathrm{dd}(2.4,3.1)$ & $70.0 \mathrm{~d}$ & $3.33 \mathrm{dd}(1.4,3.2)$ & $70.1 \mathrm{~d}$ \\
\hline 5 & & $55.6 \mathrm{~d}$ & $2.07 \mathrm{dt}(1.4,6.7)$ & $59.7 \mathrm{~d}$ \\
\hline 6 & $2.85 \sim 3.154(5 \mathrm{H})$ & $61.7 \mathrm{t}$ & $2.91 \mathrm{dd}(6.7,10.8)$ & $62.2 \mathrm{t}$ \\
\hline & & & $2.98 \mathrm{dd}(6.7,10.8)$ & \\
\hline
\end{tabular}

Chemical shifts of protons and carbons are given relative to TMS, the external standard, and $\mathrm{CH}_{3} \mathrm{CN}(\delta 1.7)$, the internal standard, respectively. Coupling constants $(\mathrm{Hz})$ are given in parentheses.

a Not assigned due to the higher order couplings.

III) and the signal of C-1 moved downfield to $\delta 174.3$ (s), which was assigned as a carbonyl group. Thus $\mathbf{3}$ was determined to be galactostatin-lactam, that is, 5-amino-5deoxygalactonic- $\delta$-lactam, $\mathrm{C}_{6} \mathrm{H}_{11} \mathrm{NO}_{5} \quad(\mathrm{MW}$ 177.16).

The D-configuration of 1 was confirmed by the negative $C D$ curve observed around $220 \mathrm{~nm}$ with 3 , since nojirimycin-lactam, which was derived from nojirimycin (D-glucopiperidinose), showed a negative $C D$ curve $^{14)}$ and a negative Cotton effect in its ORD curve. ${ }^{16)}$ The configuration of 3 is similar to that of nojirimycin-lactam except for the proton at the C-4 position. Furthermore, strong inhibition of the activities of many $D^{-}$ galactosidases by $\mathbf{1}$ shows that it is the substrate analogue for these enzymes. ${ }^{17)}$ Therefore, it is certain that galactostatin has the D-configuration.

The EI-MS spectrum of 4 showed the parent ion at $m / z 164\left(\mathrm{M}^{+}+1\right)$, the base ion at $m / z$ $132\left(\mathrm{M}^{+}-\mathrm{CH}_{2} \mathrm{OH}\right)$ and the metastable ion at $m^{*} / z 98.5\left(m_{1} / z 132 \rightarrow m_{2} / z 114\right)$. Clearly, the fragmentation pattern showed the successive release of hydroxymethylene and water. Thus, the molecular formula of $\mathbf{4}$ was deduced to be $\mathrm{C}_{6} \mathrm{H}_{13} \mathrm{NO}_{4}$ (MW 163.17), corresponding to deoxygalactostatin. The signal patterns of NMR spectra were well separated, and all proton and carbon signals were assigned as shown in Table III. Compound $\mathbf{4}$ was obtained by reduction at the $\mathrm{C}-1$ position of $\mathbf{1}$, and two protons were assigned to the axial $1-\mathrm{H}(\delta 1.70)$ and equatorial $1-\mathrm{H}(\delta 2.45)$. These results showed that the stereochemical configurations of $\mathbf{4}$ and $\mathbf{1}$ are identical. Thus, the structure of $\mathbf{4}$ is concluded to be 5-amino-1,5-dideoxygalactopyranose (1-deoxygalactostatin).

Galactostatin (1) is a potent inhibitor of $\beta$ galactosidases. Its derivatives are also inhibitors of the same enzymes although they are not as strong as 1. However, the derivative, 2hydroxymethyl-5-hydroxypyridine, showed loss of the inhibitory activity against $\beta$-galactosidases. Since 1 exists in $\alpha$ and $\beta$ anomer forms, inhibition of $\alpha$-galactosidase activities was also expected, and this compound did strongly inhibit the $\alpha$-galactosidases. These inhibitory activities against galactosidases and kinetic studies on enzyme inhibition will be reported in the next paper. ${ }^{17)}$

In addition to the enzyme inhibition, galactostatin and its derivatives showed some antivirus activities. The $50 \%$ inhibition values for plaque formation ( $\left.\mathrm{ID}_{50}\right)$ against Coxsackie virus A9 were $200 \mu \mathrm{g} / \mathrm{ml}(\mathbf{1}), 360 \mu \mathrm{g} / \mathrm{ml}$ (2), 125 $\mu \mathrm{g} / \mathrm{ml}$ (3) and $250 \mu \mathrm{g} / \mathrm{ml}(4)$. No antimicrobial activity, however, was observed.

\section{EXPERIMENTAL}

Instrumentation. Melting points were determined with a Yanagimoto hot-stage microscope and were uncorrected. 
IR spectra were recorded with $\mathrm{KBr}$ tablets with a Jasco A702 spectrometer. Mass spectra were recorded with a Hitachi RMU-8GN mass spectrometer. ${ }^{1} \mathrm{H}-\mathrm{NMR}$ spectra were recorded at $200 \mathrm{MHz}$ with TMS as an external standard with a Varian XL-200 spectrometer, and ${ }^{13} \mathrm{C}$ NMR spectra at $25 \mathrm{MHz}$ with $\mathrm{CH}_{3} \mathrm{CN}(\delta 1.7)$ as an internal standard with a Varian XL-100A spectrometer.

Thin-layer chromatography $(T L C)$. TLC was carried out as described previously. ${ }^{4)}$ The solvent systems were (A) $\mathrm{CH}_{3} \mathrm{CN}-\mathrm{AcOH}-\mathrm{H}_{2} \mathrm{O}(5: 1: 2)$, (B) $\mathrm{CHCl}_{3}-\mathrm{MeOH}$-conc. $\mathrm{NH}_{4} \mathrm{OH}(1: 2: 1)$, (C) $\mathrm{BuOH}-\mathrm{AcOH}-\mathrm{H}_{2} \mathrm{O}(3: 1: 1)$ and (D) $\mathrm{CHCl}_{3}-\mathrm{CH}_{3} \mathrm{CN}-\mathrm{MeOH}(2: 2: 1)$.

Purification of galactostatin (1) from its bisulfite adduct (2). Compounds 1 and 2 were prepared as described in the previous paper. ${ }^{4)}$ A purified and concentrated solution of 1 was obtained from the culture filtrate (7.6l) of Streptomyces lydicus PA-5726 by ion exchange chromatographies. Crystals of 2 were obtained by adding $6 \%$ sulfurous acid to the concentrated solution. Recrystallization from hot water and $\mathrm{EtOH}$ gave colorless needles of $2(3240 \mathrm{mg}, 50 \%$ yield $), \mathrm{mp} 133 \sim 135^{\circ} \mathrm{C} . R f=$ 0.55 (solvent A), $0.54(\mathrm{~B}) \cdot[\alpha]_{\mathrm{D}}^{23}+17.2^{\circ}(c=0.5$, water). IR $v_{\max }(\mathrm{KBr}) \mathrm{cm}^{-1}: 3440,3400,3240,2980,1595,1450,1400$, $1330,1205,1140,1100,1050,930,720,625$. NMR $\left(\mathrm{D}_{2} \mathrm{O}\right)$ : ${ }^{1} \mathrm{H}, \delta 2.83(1 \mathrm{H}, \mathrm{dt}, J=1.2,6.7 \mathrm{~Hz}, 5-\mathrm{H}), 3.03(1 \mathrm{H}, \mathrm{dd}, J=$ $2.9,9.0 \mathrm{~Hz}, 3-\mathrm{H}), 3.20\left(2 \mathrm{H}, \mathrm{d}, J=6.7 \mathrm{~Hz}, 6,6^{\prime}-\mathrm{H}\right), 3.41$ $(1 \mathrm{H}, \mathrm{d}, J=10.1 \mathrm{~Hz}, 1-\mathrm{H}), 3.50(1 \mathrm{H}, \mathrm{dd}, J=1.2,2.9 \mathrm{~Hz}, 4-$ H), $3.52(1 \mathrm{H}, \mathrm{dd}, J=9.0,10.1 \mathrm{~Hz}, 2-\mathrm{H}) ;{ }^{13} \mathrm{C}, \delta 59.9(\mathrm{t}, \mathrm{C}-$ 6), $60.4(\mathrm{~d}, \mathrm{C}-5), 67.6(\mathrm{~d}, \mathrm{C}-2), 68.4(\mathrm{~d}, \mathrm{C}-4), 72.7(\mathrm{~d}, \mathrm{C}-1)$, 74.6 (d, C-3). EI-MS $m / z(\%): 161\left(\mathrm{M}^{+}-82,0.1\right), 143(9)$, 125 (5), 124 (5), $112(28), 96(28), 94$ (7), 64 (51), 48 (100). Anal. Found: C, 27.39; H, 5.59; N, 5.39; S, 12.10. Calcd. for $\mathrm{C}_{6} \mathrm{H}_{13} \mathrm{NO}_{7} \mathrm{~S} \cdot \mathrm{H}_{2} \mathrm{O} ; \mathrm{C}, 27.59 ; \mathrm{H}, 5.79 ; \mathrm{N}, 5.36 ; \mathrm{S}$, $12.27 \%$.

To obtain 1 in the free state, $2(1 \mathrm{~g})$ was hydrolyzed by treatment with Dowex- $2 \times 8\left(\mathrm{OH}^{-}\right)$resin $(5 \mathrm{~g})$ in water $(10 \mathrm{ml})$. The mixture was applied to a column of the same resin, and effluent was concentrated in vacuo and then precipitated with EtOH to give a white amorphous powder of $1(628 \mathrm{mg}, 92 \%$ from 2$), \mathrm{mp} 94 \sim 98^{\circ} \mathrm{C} . \quad R f=0.39$ (solvent A), $0.29(\mathrm{~B}), 0.28(\mathrm{C}) .[\alpha]_{\mathrm{D}}^{23}+85.6^{\circ}(c=1.0$, water). Anal. Found: C, 38.26; H, 7.47; N, 7.51. Calcd. for $\mathrm{C}_{6} \mathrm{H}_{13} \mathrm{NO}_{5} \cdot 1 / 2 \mathrm{H}_{2} \mathrm{O} ; \mathrm{C}, 38.30 ; \mathrm{H}, 7.50 ; \mathrm{N}, 7.44 \%$.

Formation of 2-hydroxymethyl-5-hydroxypyridine from 1. A solution of $1(200 \mathrm{mg})$ in dry $3 \% \mathrm{HCl}-\mathrm{MeOH}(4 \mathrm{ml})$ was heated at $80^{\circ} \mathrm{C}$ for $3 \mathrm{hr}$ under nitrogen gas. The mixture was neutralized, dried, dissolved in water and then extracted with $\mathrm{CHCl}_{3}$. After purification on a silica gel column with $\mathrm{CHCl}_{3}-\mathrm{CH}_{3} \mathrm{CN}-\mathrm{MeOH}(4: 4: 1)$, crystallization with $\mathrm{CHCl}_{3}$ gave colorless needles $(67.3 \mathrm{mg}$, $48 \%$ from 1 ), $\mathrm{mp} 124 \sim 126^{\circ} \mathrm{C} . R f=0.73$ (solvent A), 0.62 (D). UV (water) $\lambda_{\max } \mathrm{nm}(\varepsilon): 252$ (2940), 280 (3110), 320 (115); UV (0.01 N HCl): 226 (4670), 289 (5980); UV $(0.01 \mathrm{~N} \mathrm{NaOH}): 243(11600), 302(4070)$. IR $v_{\max }(\mathrm{KBr})$ $\mathrm{cm}^{-1}: 3460,2460,1770,1575,1275,1215,1080,830,660$. NMR $\left(\mathrm{D}_{2} \mathrm{O}, 95^{\circ} \mathrm{C}\right):{ }^{1} \mathrm{H}, \delta 4.31(2 \mathrm{H}, 7-\mathrm{H}), 7.04(2 \mathrm{H}, 3,4-$ $\mathrm{H}), 7.76(\mathrm{lH}, 6-\mathrm{H}) ;{ }^{13} \mathrm{C}, \delta 64.3(\mathrm{t}, J=144.4 \mathrm{~Hz}, \mathrm{C}-7)$, $123.9(\mathrm{~d}, J=167.4 \mathrm{~Hz}, \mathrm{C}-3), 126.6(\mathrm{~d}, J=165.2 \mathrm{~Hz}, \mathrm{C}-4)$, $137.0(\mathrm{~d}, J=179.4 \mathrm{~Hz}, \mathrm{C}-6), 150.6(\mathrm{~s}, \mathrm{C}-2), 154.0(\mathrm{~s}, \mathrm{C}-$ 5). EI-MS $m / z(\%): 125\left(\mathrm{M}^{+}, 36\right), 124\left(\mathrm{M}^{+}-1,44\right)$, $108\left(\mathrm{M}^{+}-\mathrm{OH}, 7\right), 96\left(3-\mathrm{OH}-\mathrm{C}_{5} \mathrm{H}_{4} \mathrm{NH}^{+}, 100\right), 94\left(\mathrm{M}^{+}\right.$ $\left.-\mathrm{CH}_{2} \mathrm{OH}, 30\right), 68$ (18), 52 (17), 41 (33), 39 (32). Anal. Found: C, 57.57; H, 5.64; N, 11.18. Calcd. for $\mathrm{C}_{6} \mathrm{H}_{7} \mathrm{NO}_{2} ; \mathrm{C}, 57.59 ; \mathrm{H}, 5.64 ; \mathrm{N}, 11.19 \%$.

Oxidation of 1 to galactostatin-lactam (3). Galactostatin (1) was oxidized with $\mathrm{I}_{2}$ according to the method of Inouye et al. ${ }^{16)}$ as follows. Solutions of $\mathrm{I}_{2}(0.2 \mathrm{~N}, 1.2 \mathrm{ml})$ and $\mathrm{NaOH}(0.2 \mathrm{~N}, 1.8 \mathrm{ml})$ were alternately added to $1(200 \mathrm{mg})$ in water $(4 \mathrm{ml})$ with stirring at room temperature. The addition was repeated 10 times within one hour, then the reaction mixture was left standing at room temperature for another hour. The solution was passed through a column of Dowex- $50 \mathrm{~W} \times 8\left(\mathrm{H}^{+} ; 1.3 \phi \times 15 \mathrm{~cm}\right)$. The effluent was mixed with $\mathrm{AgCO}_{3}(2.2 \mathrm{~g})$, followed by stirring for $30 \mathrm{~min}$. The filtrate was passed through a column of Dowex$50 \mathrm{~W} \times 8\left(\mathrm{H}^{+} ; 1.3 \phi \times 10 \mathrm{~cm}\right)$, neutralized with Amberlite IRA-47( $\left(\mathrm{OH}^{-}\right)$and then concentrated to a small volume in vacuo. The solution was kept at $4^{\circ} \mathrm{C}$ with the addition of EtOH to give crystals, and recrystallization with water and EtOH gave colorless needles of $\mathbf{3}$ ( $105 \mathrm{mg}, 53 \%$ from $\mathbf{1}$ ), $\mathrm{mp} 204 \sim 206^{\circ} \mathrm{C} . R f=0.61$ (solvent A), 0.34 (C). $[\alpha]_{\mathrm{D}}^{23}$ $+122.0^{\circ}(c=1.0$, water). UV (water) $\lambda \mathrm{nm}(\varepsilon): 220(900)$, $205 \max (4300) . \mathrm{CD}$ (water): $[\theta]_{265} 0,[\theta]_{220}-23,800,[\theta]_{210}$ 0. IR $v_{\max }(\mathrm{KBr}) \mathrm{cm}^{-1}: 3400,3320,3230,2900,1660,1630$, $1470,1420,1340,1160,1135,1120,1100,1080,1060,1020$, 880,830 . EI-MS $m / z \quad(\%) ; 178 \quad\left(\mathrm{M}^{+}+1,9\right), 159$ $\left(\mathrm{M}^{+}-\mathrm{H}_{2} \mathrm{O}, \quad 28\right), \quad 148 \quad\left(\mathrm{M}^{+}-\mathrm{CHO}, \quad 15\right), \quad 146$ $\left(\mathrm{M}^{+}-\mathrm{CH}_{2} \mathrm{OH}, 48\right), 129(24), \mathrm{l} 18(17), 99(27), 73(58), 60$ (100), 42 (61), 30 (76). Anal. Found: C, 40.40; H, 6.07; N, 7.88. Calcd. for $\mathrm{C}_{6} \mathrm{H}_{11} \mathrm{NO}_{5} ; \mathrm{C}, 40.68 ; \mathrm{H}, 6.26 ; \mathrm{N}, 7.91 \%$.

Reduction of 1 to 1-deoxygalactostatin (4). A mixture of $1(200 \mathrm{mg}), \mathrm{AcOH}(0.1 \mathrm{ml})$ and $\mathrm{PtO}_{2}(40 \mathrm{mg})$ in $50 \%$ EtOH was stirred under hydrogen gas for $5 \mathrm{hr}$. The catalyst was removed by centrifugation and filtration. The solution was passed through a column of Dowex- $2 \times 8 \quad\left(\mathrm{OH}^{-}\right.$; $1.3 \phi \times 5 \mathrm{~cm}$ ) and then evaporated to a syrup in vacuo. This syrup was dissolved in a small amount of $\mathrm{MeOH}$ and then precipitated with acetone. Reprecipitation with $\mathrm{EtOH}$ and acetone gave a white amorphous powder of $\mathbf{4}(108 \mathrm{mg}$, $59 \%$ from 1), mp $218 \sim 221^{\circ} \mathrm{C}$ (decomp.). $R f=0.40$ (solvent A), $0.49(\mathrm{~B}), 0.29(\mathrm{C}) \cdot[\alpha]_{\mathrm{D}}^{23}+52.8(c=1.0$, water $)$. IR $v_{\max }(\mathrm{KBr}) \mathrm{cm}^{-1}: 3600 \sim 3200,2900,1640,1450,1400$, $1360,1290,1230,1050,855$. EI-MS $m / z(\%): 164\left(\mathrm{M}^{+}+1\right.$, 5), $146\left(\mathrm{M}^{+}-\mathrm{OH}, 0.8\right), 132\left(\mathrm{M}^{+}-\mathrm{CH}_{2} \mathrm{OH}, 100\right), 114(5)$, $98.5\left(m^{*} / z, m / z 132 \rightarrow m / z 114\right), 72(20), 60$ (41). Anal. Found: $\mathrm{C}, 43.68 ; \mathrm{H}, 7.93 ; \mathrm{N}, 8.31$. Calcd. for $\mathrm{C}_{6} \mathrm{H}_{13} \mathrm{NO}_{4} \cdot 1 / 10 \mathrm{H}_{2} \mathrm{O} ; \mathrm{C}, 43.68 ; \mathrm{H}, 8.07 ; \mathrm{N}, 8.49 \%$. 
Acknowledgments. The authors are grateful to their colleagues at Shionogi Research Laboratories; Dr. K. Kuriyama for measuring the IR spectra and optical rotations, Dr. Y. Nakagawa for the mass spectra, Dr. A. Terui for the NMR spectra, and Dr. S. Seo and Mr. T. Honma for their helpful advice.

\section{REFERENCES}

1) T. Aoyagi, M. Kumagai, T. Hazato, M. Hamada, T. Takeuchi and H. Umezawa, J. Antibiot., 28, 555 (1975).

2) T. Aoyagi, T. Hazato, M. Kumagai, M. Hamada, T. Takeuchi and H. Umezawa, J. Antibiot., 28, 1006 (1975).

3) T. Hazato, T. Aoyagi and H. Umezawa, $J$. Antibiot., 32, 212 (1979).

4) Y. Miyake and M. Ebata, Agric. Biol. Chem., 52, 153 (1988).

5) H. Paulsen, Angew. Chem. Int. Ed., 5, 495 (1966).

6) T. Niwa, S. Inouye, T. Tsuruoka, Y. Koaze and T. Niida, Agric. Biol. Chem., 34, 966 (1970).

7) S. Murao and S. Miyata, Agric. Biol. Chem., 44,
$219(1980)$

8) B. Saunier, R. D. Kilker, Jr., J. S. Tkacz, A. Quaroni and A. Herscovics, J. Biol. Chem., 257, 14155 (1982).

9) D. E. Dorman and J. D. Roberts, J. Am. Chem. Soc., 92, 1355 (1970).

10) P. E. Pfefter, K. M. Valentine and F. W. Parrish, $J$. Am. Chern. Soc., 101, 1265 (1979).

11) K. Bock and C. Pedersen, in "Advances in Carbohydrate Chemistry and Biochemistry," Vol. 41, ed. by R. S. Tipson and D. Horton, Academic Press, New York, 1983, pp. $27 \sim 66$.

12) S. F. Mason, J. Chem. Soc, 1959, 1253.

13) H. Paulsen, Angew. Chem. Int. Ed., 1, 454 (1962).

14) S. Inouye, T. Tsuruoka and T. Niida, J. Antibiot., Ser. A, 19, 288 (1966)

15) T. Niwa, T. Tsuruoka, H. Goi, Y. Kodama, J. Itoh, S. Inouye, Y. Yamada, T. Niida, M. Nobe and Y. Ogawa, J. Antibiot., 37, 1579 (1984).

16) S. Inouye, T. Tsuruoka, T. Ito and T. Niida, Tetrahedron, 24, 2125 (1968).

17) Y. Miyake and M. Ebata, Agric. Biol. Chem., submitted. 